Original Research Article

\title{
A comparative study of antinociceptive effect of paroxetine with pethidine in acute pain in albino rats
}

\author{
Manju Gari, Kumari Ranjeeta*, Lakhan Majhee, Akhilesh Kumar, Sumit Kumar Mahato
}

Department of Pharmacology, Rajendra Institute of Medical Sciences (RIMS), Ranchi University, Ranchi, Jharkhand, India

Received: 29 April 2017

Accepted: 24 May 2017

*Correspondence to:

Dr. Kumari Ranjeeta,

Email: ranjita78700@gmail.com

Copyright: (C) the author(s), publisher and licensee Medip Academy. This is an openaccess article distributed under the terms of the Creative Commons Attribution NonCommercial License, which permits unrestricted noncommercial use, distribution, and reproduction in any medium, provided the original work is properly cited.

\begin{abstract}
Background: Pain is the most common reason patients seek medical care. Increased level of monoamines (serotonin and norepinephrine) in synaptic clefts lead to changes in pain threshold and induce antinociception. The study was carried out to evaluate antinociceptive effect of paroxetine in albino rats and to probe into its possible mechanism of action. The study was carried out to evaluate anti-nociceptive effect of paroxetine in albino rats.

Methods: Male Albino rats of average weight $150-240 \mathrm{gms}$ were used. The drugs used were paroxetine $5 \mathrm{mg} / \mathrm{Kg}$, pethidine $5 \mathrm{mg} / \mathrm{kg}$ (standard drug). Antinociceptive effect tested by using thermal method i.e. Tail flick response and Tail warm water immersion method.

Results: In this study, Anti-nociceptive effect of respective drugs were measured by using two methods i.e. tail flick test and tail warm water immersion method at $0 \mathrm{~min} ., 30 \mathrm{~min} ., 60 \mathrm{~min}$. and 90min.after administration of drugs. Reaction time started to increase from baseline at $0 \mathrm{~min}$. and peak effect was seen at $60 \mathrm{~min}$. then it started to decrease at $90 \mathrm{~min}$. in almost all the groups except in control group.

Conclusions: Paroxetine have significant analgesic effect in acute pain, which may be mediated via central and peripheral mechanisms. Efficacy of Paroxetine is almost equal to that of standard drug pethidine in acute pain management.
\end{abstract}

Keywords: Antinociception, Paroxetine, Selective serotonin reuptake inhibitors

\section{INTRODUCTION}

The analgesic properties of psychotropics were reported shortly after their introduction into psychiatric practice. ${ }^{1}$ Recently, numerous open and controlled studies have shown that antidepressant drugs also have analgesic activity and are effective in mixed and chronic pain. ${ }^{2}$ It has also been reported that the analgesic effect of antidepressants is independent of their antidepressant action and occurs at lower doses with a faster onset of action in a clinical situationn. ${ }^{3,4}$ This effect can be explained by several pharmacological mechanisms. Some TCAs block sodium channel, which may contribute to their anti-hyperalgesic efficacy. ${ }^{5}$ They also apparently block calcium ion channels. ${ }^{6,7}$ However, it has also been considered that antidepressants including SSRI and SNRI modulate pain perception by blocking the reuptake of monoaminergic neurotransmitters in noradrenergic and serotonergic systems, which originate from brain stem and project to the spinal cord dorsal horn and therefore increased level of monoamines (serotonin and norepinephrine) in synaptic clefts lead to changes in pain threshold and induce antinociception. ${ }^{8,9}$

Moreover, the anti-histaminergic action of TCA may have a general analgesic effect. ${ }^{10}$ Recent findings have shown that antidepressants interact with the opioidergic system and that they act as NMDA receptor antagonists. ${ }^{11}$ Because of numerous undesirable side effects of traditional tricyclics, the selective serotonin reuptake inhibitors (SSRIs), with a favourable side effect profile, are preferred. ${ }^{12}$ Paroxetine is the most potent inhibitor of 
serotonin re-uptake among SSRIs. ${ }^{13,14}$ for treatment of depressive disorders and as an adjuvant drug in chronic pain. ${ }^{13,15}$

The antidepressant action occurs after several weeks of treatment, while analgesic action is prominent after an acute single dose administration, which is at a lower dosage than that required for its antidepressant effect. ${ }^{16,17}$ There are a lot of studies were done on role of SSRI in chronic pain management but not much on role of SSRI in acute pain management. Study done by Yatish et al, shown the potential anti-nociceptive effect of paroxetine in acute pain management and it was almost equal to that seen with standard drug pentazocine. ${ }^{18}$ The result of that study was consistent with that of done by Erdem et al. ${ }^{19}$ The present study was undertaken to demonstrate the effect of paroxetine, a potent SSRI on acute pain. In one study antinociceptive effect of paroxetine was tested using hot plate method in mice. It showed significant antinociceptive effects at a dose of $5 \mathrm{mg} / \mathrm{kg}$ therefore purpose of the present studies was to evaluate the analgesic efficacy of selective serotonergic reuptake inhibitor in acute nociceptive pain models in albino rats.

\section{METHODS}

Healthy male wistar Albino rats were procured from authorized supplier from Kolkata and rats weighing between 150-240gms were taken for the present study. The animals were kept in clean and dry cages with $12 \mathrm{~h}: 12 \mathrm{~h}$ light-dark cycle at normal room temperature and humidity. They were acclimatized to the available housing condition in the cages for the period of 2 weeks before using for the experiment and were fed with standard laboratory diet consisting of soaked black gram (Kala Chana), maize and water was given ad libitum. Arrangements were made to ensure regular cleaning of cages and disposal of excreta and urine. The experimental protocol was conducted according to the guidelines.

\section{Test drugs and dose calculation}

Dose of the drugs were calculated from the standard clinical human dose on the basis of surface area. Surface area ratio of $200 \mathrm{~g}$ rat for $70 \mathrm{~kg}$ man is $0.018 .^{20,21}$ Thus, human dose of any drug (for a $70 \mathrm{~kg}$ person) multiplied by 0.018 gives the value of that drug for $200 \mathrm{~g}$ of rat. Multiplying the product with 5 gives $\mathrm{mg} / \mathrm{kg}$ value. The human dose of pethidine $50 \mathrm{mg} /$ day, Paroxetine $60 \mathrm{mg}$ /day were given to rats according dose adjustment criteria intraperitoneally.

The entire experiment was carried out in "Department of Pharmacology and Therapeutics, Rajendra Institute of Medical Sciences, Ranchi”.

\section{Inclusion criteria}

- Healthy and active male wistar rats were included for the study.
- $\quad$ Rats weighing 150-240grams were used.

\section{Exclusion criteria}

- Diseased and inactive rats were excluded from the study.

- Rats with weight less than 150 grams and above 240grams were excluded from the study.

Study animals were divided into three groups with six animals in each group. The rats were kept in three animal cages. Rats were given different treatment i.p weekly i.e. on day $0,7^{\text {th }}, 14^{\text {th }}, 21^{\text {st }}, 28^{\text {th }}$ and $35^{\text {th }}$ in the morning hour. Experiments were conducted between 9:00 and 17:00 h to minimize the diurnal variation. Antinociceptive effect was tested by thermal method i.e. tail flick method and tail immersion method.

\section{Tail flick method ${ }^{22}$}

In tail flick method rat tail was exposed to heated nichrome wire, Strength of current used was 5ampere. Tail-withdrawl from heat (flicking response) was taken as the end point. Rat withdrawn its tail within 3-5sec. Reaction time $10 \mathrm{sec}$. was considered as maximal analgesia and tail was removed from the source of heat to avoid tissue damage.

\section{Tail immersion method using hot water $\left(55^{\circ} C\right)^{23}$}

Lower $5 \mathrm{~cm}$ portion of tail was marked. Marked portion of tail is immersed into cup with hot water immersed at $55^{\circ} \mathrm{C}$. Within few seconds rat reacts by withdraws its tail and reaction time was recorded by stopwatch. Cut-off time was 8 sec.

Table 1: The details of groups.

\begin{tabular}{|llll|}
\hline Groups & $\begin{array}{l}\text { Number } \\
\text { of rats }\end{array}$ & $\begin{array}{l}\text { Drugs } \\
\text { Distilled } \\
\text { water }\end{array}$ & $\begin{array}{l}5 \mathrm{ml} / \mathrm{kg} \\
\mathrm{BW}\end{array}$ \\
\hline $\begin{array}{l}\text { Group A: Normal } \\
\text { control }\end{array}$ & 6 & Pethidine & $\begin{array}{l}5 \mathrm{ml} / \mathrm{kg} \\
\mathrm{BW}\end{array}$ \\
\hline $\begin{array}{l}\text { Group B: Standard } \\
\text { group with pethidine }\end{array}$ & 6 & Paroxetine & $\begin{array}{l}5 \mathrm{ml} / \mathrm{kg} \\
\mathrm{BW}\end{array}$ \\
\hline $\begin{array}{l}\text { Group C: Test group } \\
\text { with paroxetine }\end{array}$ & 6 & & \\
\hline
\end{tabular}

\section{Statistical analysis}

Statistical analysis of data was carried out by employing analysis of variance. One way ANOVA test was used to compare the effect of drugs on different group. Post hoc analysis was done by using Turkeys HSD (honestly significant difference) test.

\section{RESULTS}

From Table 2, it clear that there was non-significant difference found when Group B was compared with 
group $\mathrm{C}$ at all-time intervals i.e. $30(\mathrm{P}=0.294), 60$ $(\mathrm{P}=0.678)$ and 90 minutes $(\mathrm{P}=1)$. Thus, both group produced a significant increase in the latency of tail flick at all-time intervals with onset producing within 30 minutes after the injection and maximum antinociceptive effect producing at 60 minutes and maintaining the effect till 90 minutes.

Table 2: Comparison of average reaction time (in sec.) between pethidine and paroxetine group by Tail Flick method.

\begin{tabular}{|llllll|}
\hline Group & Parameter & \multicolumn{4}{ll}{ Time interval (min) } \\
\hline & & $\mathbf{0}$ & $\mathbf{3 0}$ & $\mathbf{6 0}$ & $\mathbf{9 0}$ \\
\hline Group & \multirow{2}{*}{ Mean \pm SD } & $7.53 \pm$ & $7.7 \pm$ & $8.25 \pm$ & $7.96 \pm$ \\
B & & 0.21 & 0.15 & 0.10 & 0.07 \\
\hline Group & \multirow{2}{*}{ Mean \pm SD } & $7.54 \pm$ & $7.69 \pm$ & $8.21 \pm$ & $7.88 \pm$ \\
C & & 0.25 & 0.25 & 0.25 & 0.17 \\
\hline Mean Difference & 0.01 & 0.06 & 0.01 & 0.03 \\
\hline Significance (p value) & 0.938 & 0.294 & 0.678 & 1 \\
\hline
\end{tabular}

From Table 3, there was non-significant difference found when group $\mathrm{B}$ was compared with group $\mathrm{C}$ at all-time intervals i.e. $30(\mathrm{P}=1), 60(\mathrm{P}=1)$ and 90 minutes $(\mathrm{P}=1)$. Thus, both group produced a significant increase in the latency of reaction time at all time intervals with onset producing within 30 minutes after the injection and maximum antinociceptive effect producing at 60 minutes and maintaining the effect till 90 minutes.

Table 3: Comparison of average reaction time (in sec.) of pethidine and paroxetine group by Tail Warm Water Immersion method.

\begin{tabular}{|lcllll|}
\hline \multirow{2}{*}{ Group } & \multirow{2}{*}{ Parameter } & \multicolumn{4}{ll}{ Time interval (min) } \\
& & $\mathbf{0}$ & $\mathbf{3 0}$ & $\mathbf{6 0}$ & $\mathbf{9 0}$ \\
\hline Group & \multirow{2}{*}{ Mean \pm SD } & $1.49 \pm$ & $3.25 \pm$ & $5.08 \pm$ & $4.09 \pm$ \\
B & & 0.06 & 0.23 & 0.15 & 0.06 \\
\hline Group & \multirow{2}{*}{ Mean \pm SD } & $1.47 \pm$ & $3.21 \pm$ & $5.05 \pm$ & $4.06 \pm$ \\
C & & 0.07 & 0.28 & 0.20 & 0.07 \\
\hline Mean Difference & 0.02 & 0.04 & 0.03 & 0.03 \\
\hline Significance (p value) & 1.00 & 1.00 & 1.00 & 1.00 \\
\hline
\end{tabular}

Table 4: Overall comparison of Tail Warm Water Immersion Method among Group A, B and C after analysis of data with one - way ANOVA.

\begin{tabular}{|llllll|}
\hline \multirow{2}{*}{ Group } & \multirow{2}{*}{ Parameter } & \multicolumn{4}{l}{ Time interval (min) } \\
& & $\mathbf{0}$ & $\mathbf{3 0}$ & $\mathbf{6 0}$ & $\mathbf{9 0}$ \\
\hline Group & \multirow{2}{*}{ Mean \pm SD } & $1.03 \pm$ & $1.04 \pm$ & $1.04 \pm$ & $1.05 \pm$ \\
A & & 0.05 & 0.03 & 0.04 & 0.03 \\
\hline Group & \multirow{2}{*}{ Mean \pm SD } & $1.49 \pm$ & $3.25 \pm$ & $5.08 \pm$ & $4.09 \pm$ \\
B & & 0.06 & 0.23 & 0.15 & 0.06 \\
\hline Group & \multirow{2}{*}{ Mean \pm SD } & $1.47 \pm$ & $3.21 \pm$ & $5.05 \pm$ & $4.06 \pm$ \\
C & & 0.07 & 0.28 & 0.20 & 0.07 \\
\hline
\end{tabular}

There was no significant difference found when before reading was compared with 30 minutes, 60 minutes and 90 minutes readings of the control group. Thus, control group didn't produce the antinociceptive effect. While group $\mathrm{B}$ and $\mathrm{C}$ produced significant antinociceptive effect.

There was no significant difference found when before reading was compared with 30 minutes, 60 minutes and 90 minutes readings of the control group. Thus, control group didn't produce the antinociceptive effect. While group $\mathrm{B}$ and $\mathrm{C}$ produced significant antinociceptive effect.

Table 5: Overall comparison of Tail Flick method among Group A, B and C after analysis of data with one-way ANOVA.

\begin{tabular}{|llllll|}
\hline \multirow{2}{*}{ Group } & \multirow{2}{*}{ Parameter } & \multicolumn{5}{l}{ Time interval (min) } \\
& & $\mathbf{0}$ & $\mathbf{3 0}$ & $\mathbf{6 0}$ & $\mathbf{9 0}$ \\
\hline Group & \multirow{2}{*}{ Mean \pm SD } & $4.57 \pm$ & $4.79 \pm$ & $4.66 \pm$ & $4.71 \pm$ \\
A & & 0.13 & 0.08 & 0.32 & 0.14 \\
\hline Group & \multirow{2}{*}{ Mean \pm SD } & $7.53 \pm$ & $7.76 \pm$ & $8.25 \pm$ & $7.96 \pm$ \\
B & & 0.21 & 0.15 & 0.10 & 0.07 \\
\hline Group & \multirow{2}{*}{ Mean \pm SD } & $7.54 \pm$ & $7.69 \pm$ & $8.21 \pm$ & $7.88 \pm$ \\
C & & 0.25 & 0.25 & 0.25 & 0.17 \\
\hline
\end{tabular}

\section{DISCUSSION}

We have seen that throughout this study period, after drug administration reaction time started to increase from baseline at $0 \mathrm{~min}$. and peak effect was seen at $60 \mathrm{~min}$. then it started to decrease at $90 \mathrm{~min}$. in almost all the groups except in group $\mathrm{A}$, this finding suggests that all the test drugs i.e. pethidine, paroxetine have antinociceptive effect. In this study, we compared paroxetine with standard drug pethidine and we got statistically non-significant data $(p>0.05)$. In our study, paroxetine induced an antinociceptive effect starting approximately $0 \mathrm{~min}$ after injection and lasting for 60 min following i.p administration this finding revealed that anti-nociceptive effect of paroxetine was comparable to pethidine. Again, reason for this effect of paroxetine is that here we used comparatively higher doses i.e. $5 \mathrm{mg} / \mathrm{kg} .{ }^{24}$ The results of this study are consistent with that of study done by C. Umamaheshwari et al, Rajani et al, Erdem et al, Masand et al and Gray et al. ${ }^{19,25-28}$ Probable mechanism for this action of paroxetine might be- control of analgesia is performed by the descending inhibitory pathways in the central nervous system (CNS). The key part of this descending system is the periaqueductal grey area (PAG). PAG receives inputs from different brain regions and is assumed to be a gate in control of nociception, especially in the dorsal horn. PAG mainly stimulates the nucleus raphe magnus (NRM) and some fibers in the spinal cord, which form synaptic connections on dorsal horn interneurons. 5-HT is the major transmitter both at these synapses and the pathway from the NRM to the substantia gelatinosa of the dorsal horn. Activation of this pathway inhibits transmission specifically in nociceptive pathways. ${ }^{29}$ The descending inhibitory pathway is probably an important spinal site of action for opioid analgesics. It is thought that the 5-HT 
descending system plays an important role in morphine analgesia. $^{30,31}$

\section{Limitations}

- Both the methods used was crude methods, some specific method could yield better result.

- Only two models of analgesic have been used in this study, yet using more models would have been better.

- Both models taken in this study was thermal model, if this study include chemical model too like formalin test then it could give better result.

\section{CONCLUSION}

The result of this study in albino rats conclude that:

- Paroxetine have significant analgesic effect in acute pain, which may be mediated via central and peripheral mechanisms.

- Efficacy of Paroxetine is almost equal to that of standard drug pethidine in acute pain management.

In our study is method used is very primitive. Further studies need to be done in various other acute pain models using different species to establish efficacy of paroxetine as an analgesic. More elaborative studies are required to elicit the molecular mechanism of pain suppression of the studied drugs and for implementing the results of this study in actual clinical setting.

Funding: No funding sources

Conflict of interest: None declared

Ethical approval: The study was approved by the Institutional Ethics Committee

\section{REFERENCES}

1. Monks. Psychotropic drugs. In: Bonica's The Management of Pain, 2 ${ }^{\text {nd }}$ Edition, Williams and Wilkins, United States of America; 1990:1677-1679.

2. Jung AC, Staiger T, Sullivan M. The efficacy of selective serotonin reuptake inhibitors for the management of chronic pain. Journal of General Internal Medicine. 1997;12(6):384-96.

3. Pilowsky I, Hallett EC, Bassett DL, Thomas PG, Penhall RK. A controlled study of amitriptyline in the treatment of chronic pain. Pain. 1982;14:169-79.

4. Onghena P, Van Hondenhobe B. Antidepressantinduced analgesia in chronic nonmalignantpain: a meta-analysis of 39 placebo-controlled studies. Pain.1992;49:205-19.

5. Dick IE, Brochu RM, Purohit Y, Kaczorowski GJ, Martin WJ, Priest BT. Sodium Channel blockade may contribute to the analgesic efficacy of antidepressants. J Pain. 2006;14:315-24.

6. Choi JJ, Huang GJ, Shafik E, Wu WH, McArdle JJ. Imipramine's selective suppression of an L-type calcium channel in neurons of murine dorsal root ganglia involves $\mathrm{G}$ proteins. J Pharmacol Exp Ther. 1992;263:49-53.

7. Chaplan SR, Pogrel JW, Yaksh TL. Role of voltage dependent calcium channel subtypes in experimental tactile allodynia. J Pharmacol Exp Ther. 1994;269:1117-23.

8. Valverde O, Mico JA, Maldonaldo R, Mellado M, Gilbert-Rahola J. Participation of opioid and monoaminergic mechanisms on the antinociceptive effect induced by tricyclic antidepressants in two behavioral pain tests in mice. Prog Neuropsychopharmacol Biol Psychiatry. 1994;18:1073-92.

9. Yokogawa F, Kiuchi Y, Ishikawa Y, Otsuka N, Masuda Y, Oguchi K, et al. An investigation of monoamine receptors involved in antinociceptive effects of antidepressants. Anesthesia and Analgesia. 2002;95(1):163-8.

10. Rumore MM, Schlichting DA. Clinical efficacy of antihistaminics as analgesics. Pain. 1986;25:7-22.

11. Gray AM, Spencer PS, Sewell RD. The involvement of the opioidergic system in the antinociceptive mechanism of action of antidepressant compounds. Br J Pharmacol. 1998;124:669-74.

12. Richelson E. Pharmacology of antidepressants, Mayo Clin. Proc. 2001;76:511-27.

13. Bourin M, Chue P, Guillon Y. Paroxetine: a review. CNS Drug Rev. 2001;7:25-47.

14. Richelson E. Pharmacology of antidepressants. Mayo Clin Proc. 2001;76:511-27.

15. Jung AC, Staiger T, Sullivan M. The efficacy of selective serotonin reuptake inhibitors for the management of chronic pain. J Gen Intern Med. 1997;12:384-9.

16. Korzeniewska-Rybicka I, Plaznik A. Analgesic effect of antidepressant drugs. Pharmacol Biochem Behav. 1998;59:331-8.

17. Coquoz D, Porchet HC, Dayer P. Central analgesic effects of desipramine, fluvoxamine and moclobemide after single oral dosing: a study in healthy volunteers. Clin Pharmacol Ther. 1993;54:339-44.

18. Yatish B, Nadia N, Patil VM. Study of antinociceptive effect of paroxetine in acute pain in albino rats. Int $\mathbf{J}$ Basic Clin Pharmacol. 2016;5(3):1022-8.

19. Erdem D, Murat K, Mine K, Cunay U, Nuri K, Ersin Y. Effect of gender on antinociceptive effect of paroxetine in hot plate test in mice Progneuro psycho pharmacol Biol Psychatr. 2006;30(2):292-6.

20. Ghosh MN. Toxicity studies In. Ghosh MN, editor, Fundamental of Experimental Pharmacology $5^{\text {th }}$ Ed, Kolkata; Hilton and company; 2011:167-209.

21. Mann MD, Crouse DA, Prentice ED. Appropriate Anomal numbers in Biomedical Research in Light of Animal Welfare Considerations, Laboratory Animal Science. 1991;41(1):6-14.

22. D'Amour FE, Smith DL. A method for determining loss of pain sensation (PDF). J Pharmacol Exp Ther. 1941;72(1):74-8. 
23. Ramabadran K, Bansinath M, Turndorf H, Puig MM. Tail immersion test for evaluation of a nociceptive reation in mice. J Pharmacol Meth. 1989;21:21-31.

24. Duman EN, Kesim M, Kadioglu M, Yaris E, Kalyoncu NI, Erciyes N. Possible involvement of opioidergic and serotonergic mechanisms in antinociceptive effect of paroxetine in acute pain $\mathrm{J}$ Pharmacol Sci. 2004 Feb;94(2):161-5.

25. Umamaheshwari C, Shanthi M, Malathi M, Parameswari R. Evaluation of Analgesic Activity of Paroxetine in Adult Male Albino Rats in Comparison with Diclofenac International Journal of Science and Research (IJSR). 2016 May;5(5).

26. Patil R, Myageri RL, Geetha. Study of Antinociceptive Effect of Paroxetine and Elucidation of Its Mechanism of Action in Acute Pain in Albino Rats, Drug Invention Today. 2012;4(6):379-80.

27. Masand PS, Narasimhan M, Patkar AA. Paroxetine for somatic pain associated with physical illness: A review, Prim. Care Companion J Clin Psychiatry. 2006;8:122-30.

28. Gray AM, Spencer PSJ, Sewell RDE. The involvement of the opioidergic system in the antinociceptive mechanism of action of antidepressant compounds, Br. J. Pharmacol. 1998;124:669-674,187.

29. Singh VP, Jain NK, Kulkarni SK. On the antinociceptive effect of fluoxetine, a selective serotonin reuptake inhibitor. Brain Res. 2001;915:218-26.

30. Auerbach S, Fornal C, Jacobs BL. Response of serotonincontaining neurons in nucleus raphe magnus to morphine, noxious stimuli, and periaqueductal gray stimulation in freely moving cats. Exp Neurol. 1985;88:609-28.

31. Iyengar S, Webster AA, Hemrick-Luecke SK, Xu JY, Simmons RM. Efficacy of duloxetine, a potent and balanced serotonin-norepinephrine reuptake inhibitor in persistent pain models in rats, J Pharmacol Exp Ther. 2004 Nov;311(2):576-84.

Cite this article as: Gari M, Kumari R, Majhee L, Kumar A, Mahato SK. A comparative study of antinociceptive effect of paroxetine with pethidine in acute pain in albino rats. Int $\mathrm{J}$ Basic Clin Pharmacol 2017;6:1728-32. 